\title{
Contributions and perspectives of chicken genomics in Brazil: from biological model to export commodity
}

\author{
E.C. JORGE 1 , A. FIGUEIRA ${ }^{2}$, M.C. LEDUR ${ }^{3}$, A.S.A.M.T. MOURA ${ }^{4}$ and L.L. \\ COUTINHO ${ }^{1 *}$
}

${ }^{1}$ Universidade de São Paulo - Escola Superior de Agricultura "Luiz de Queiroz", Departamento de Zootecnia, Av. Pádua Dias, 11, Piracicaba, SP, 13418-900, Brazil; ${ }^{2}$ Universidade de São Paulo - Centro de Energia Nuclear na Agricultura, Av Centenário, 303, Piracicaba, SP, 13400-970, Brazil; ${ }^{3}$ Embrapa Suínos e Aves, Genética e Melhoramento Animal, BR 153, Km 110, Vila Tamanduá, CP 21, Concórdia, SC, 89700-000, Brazil; ${ }^{4}$ Universidade Estadual Paulista Júlio de Mesquita Filho, Faculdade de Medicina Veterinária e Zootecnia de Botucatu, Departamento de Produção e Exploração Animal, Rubião Junior s/n Fazenda Lageado, CP 560, Botucatu, SP, 18618-000, Brazil

*Corresponding author: llcoutin@ esalq.usp.br

Chicken is one of the most important sources of animal protein for human consumption, and breeding programmes have been responsible for constant improvements in production efficiency and product quality. Furthermore, chicken has largely contributed to fundamental discoveries in biology for the last 100 years. In this article we review recent developments in poultry genomics and their contribution to adding functional information to the already existing structural genomics, including the availability of the complete genome sequence, a comprehensive collection of mRNA sequences (ESTs), microarray platforms, and their use to complement QTL mapping strategies in the identification of genes that underlie complex traits. Efforts of the Brazilian Poultry Genomics Programme in this area resulted in generation of a resource population, which was used for identification of Quantitative Trait Loci (QTL) regions, generation of ESTs and candidate gene studies that contributed to furthering our understanding of the complex biological processes involved in growth and muscular development in chicken.

Keywords: EST; microarray; muscle development; poultry genetics; QTL mapping

(C) World's Poultry Science Association 2007

World's Poultry Science Journal, Vol. 63, December 2007

Received for publication May 4, 2007

Accepted for publication June 6, 2007 
Chicken genomics in Brazil: E.C. Jorge et al.

\section{Introduction}

The use of chicken (Gallus gallus) as a model system in biology has largely contributed to fundamental discoveries and scientific progresses. The importance of some of these scientific developments, such as the demonstration that B cells are a distinct class of small lymphocytes and the discovery that a virus can cause tumour formation, might be regarded as great historical scientific milestones (Brown et al., 2003). Chick-based experimental systems have continued to lead to important scientific breakthroughs, such as the discovery of gene conversion as a mechanism for antibody diversification (Reynaud et al., 1987); the identification of DT40 cell line (Buerstedde; Takeda, 1991); and the revelation of alternative strategies of molecular and genomic evolution in the vertebrate immune system (Kaufmann, 1999).

Chicken has extensively been used as model organism for the last 100 years for several reasons. Birds are the evolutionary connection between mammals and other vertebrates, and chicken serves as the main laboratory model for $~ 9,600$ extant avian species (Hillier et al., 2004). Years of selection transformed chicken into an excellent model for understanding the genetic basis of phenotypic characteristics, due to its remarkable diversity among domesticated species (Andersson; Georges, 2004; Burt, 2005). Chicken embryos are also ideal for studying vertebrate development, because embryos develop in morphologically similar ways to mammals, yet, unlike mammalian embryos, are accessible to study with an in ovo development instead of in utero. Most of the knowledge about human limb formation has been uncovered through studies of chicken (Schmutz; Grimwood, 2004).

Further, chicken meat is one of the most important sources of animal protein for humans, without any major dietary restriction, such as swine (avoided by Muslims and Jewish) or beef cattle (not consumed by Hindus), and is therefore a common denominator for coexistence. In Brazil, chicken meat production represents an important component of agribusiness. The realized yield reached during the last few years has placed Brazil among the main world producers and exporters.

Research on chicken biology promotes basic sciences, with potential impact in other areas, including human health, food production and environmental conservation. Recent developments in poultry genomics offer new insights on avian biology, which facilitate applications in agriculture through increased efficiency in breeding and knowledge of animal physiology. Hence, the objective of this work was to review the current progress of Poultry Genomics and its future perspectives in breeding and biological research, highlighting developments in Brazil.

\section{Background on poultry genetics and genomics}

Poultry breeding programmes have relied on phenotype to select superior individuals as parents for the future generations, employing a classical breeding approach. This approach has been improved during the 20th century by the introduction of advanced statistical genetic procedures to better assess heritability of traits and breeding values of animals. Many years of selection resulted in enormous advances in chicken characteristics, associated with yield and adaptation. The live weight of broiler chicken is one of the best examples of the progress achieved throughout years of selection and breeding. In 1930, for instance, 105 days were needed for chickens to reach 1,500 g live weight (UBA Annual Report, 2005/2006). Nowadays, commercial broilers reach 2,300 g in only 42 days, decreasing the slaughter age by two months, with feed conversion rates decreasing proportionally, from 3.5 in 1930 to 1.8 in 2005 (UBA Annual Report, 2005/2006). 
Despite clear successful gains obtained because of selection, the biological limits for genetic progress in egg and meat production were theoretically estimated to be achieved within the next twenty years (Burt, 2002). Conversely, small random molecular changes in genes (Hill, 2005) and selection-induced genetic variation (Carlborg et al., 2006; Siegel et al., 2006) were suggested as potential mechanisms responsible for widening genetic variability, which may enable the surpass of these theoretical plateaus. Consequently, the progress, or even the maintenance, of current yield constantly requires changes in the poultry industry's priorities. New changes may involve cost reduction or the development of new products (e.g. nutraceuticals), together with offering novel solutions for problems associated with a number of undesirable traits resulting from years of selection (Burt, 2005). For instance, there has been an increase in the incidence of diseases, such as ascites and lameness; reduced fertility; and a decrease in resistance to infectious diseases in broiler chicken (Burt, 2005).

To surpass the current genetic bottleneck, incorporation of new alleles by hybridization and/or by direct manipulation would be required. Gene introgression might provide a solution for some of these genetic limitations. New alleles could be introduced into commercial populations by directed crossings with wild populations, which may have conserved a wider set of alleles. Introgressed wild alleles would warrant continuous genetic progress in these lines by transgressive segregation. On the other hand, limitations of introgression include linkage drag and shortage of recognized or defined wild species.

Marker-assisted selection (MAS) was developed as an alternative to reduce linkage drag, promoting direct changes in DNA frequencies by selecting individuals that carry favourable polymorphisms at genetic markers and/or genes associated with economically important traits. DNA-based molecular markers, originally developed by Botstein et al. (1980) offer the potential to assist breeders by directly evaluating the genetics of a trait with minimal environmental influences. Selection of superior individuals was supposed to become a faster and more efficient process. However, the potential of molecular markers in animal selection has not been fully developed, except for mutations affecting monogenic traits in certain target populations. There are many examples of mutations listed at OMIA database (Online Mendelian Inheritance in Animals, http://omia.angis.org.au) that can be screened using molecular tools in livestock breeding. Among the chicken mutations listed at OMIA, those linked to sex have been exploited for sexing day-old chickens in specific populations and/or breeds, including mutants for the Feathering gene (Chambers et al., 1993; OMIA380). Dwarf mutations (Agarwal et al., 1994; OMIA309) can be exploited for selection of animals for reduced feed consumption. However, to our knowledge, there is no report about the use of mutations in poultry breeding programmes as genetic markers to improve production or meat quality. Nevertheless, there is extensive use of molecular tests in swine and cattle (Traas et al., 2006; Dekkers, 2004). Characterization of mutations with important effects on relevant phenotypic traits remains a critical step to develop useful markers for selection. A large majority of important economic traits exhibit a polygenic pattern of inheritance, controlled by several genes with small individual effects, each largely influenced by the environment. Identification of genomic regions containing loci associated with quantitative traits (Quantitative Trait Loci or QTL) became possible with the development of saturated genetic maps using molecular markers.

The development of high-density genetic maps was initially limited by the availability of sufficiently polymorphic genetic markers, but microsatellites or simple sequence repeats (SSR; Tauz, 1989) and single nucleotide polymorphism (SNPs; Collins et al., 1998) have enabled efficient mapping. Highly saturated genetic maps together with powerful statistical methods have allowed the dissection of complex traits into Mendelian units with identification of specific alleles. 


\section{Chicken genomics in Brazil: E.C. Jorge et al.}

The use of segregation analysis in informative families or experimental crosses to map QTLs is now well established in animal genetics, including poultry. Currently, there are chicken genetic maps with various levels of resolution, based either on genetic or physical linkage, including FISH (Fluorescence in situ Hybridization) and radiation hybrid mapping (Morisson et al., 2002). The consensus chicken genetic linkage map includes 2,261 genetic loci covering a total of $\sim 4,200 \mathrm{cM}$ on 53 linkage groups (Schmid et al., 2005). QTLs have been mapped along the genome for the most important economic traits, affecting animal growth (van Kaam et al., 1998; 1999; Tatsuda, Fujinaka, 2001); feed efficiency (van Kaam et al., 1999); carcass traits (van Kaam et al., 1999); resistance to Marek's disease (Vallejo et al., 1998; Yonash et al., 1999; Lipkin et al., 2002); body fat (Ikeobi et al., 2002); and egg quality (Tuiskula-Haavisto et al., 2002; Wardecka et al., 2002) (reviewed by Romanov et al., 2004; Hocking, 2005 and Abasht et al., 2006). A chicken QTL database was recently organized at the site http://www.animalgenome.org/QTLdb/chicken.html, integrating available public chicken QTL data in a chicken consensus linkage map (Schmid et al., 2005).

However, the adoption of QTLs in MAS schemes in animal breeding has not been completely realized so far, due to various technical limitations to identify the molecular basis of a QTL. First, it has been difficult to precisely locate a QTL in a chromosome. QTLs are determined statistically, and precision localization demands genotyping and phenotyping a large number of individuals, with the simultaneous reduction of environmental effects. Imprecise QTL location hinders the definition of the exact chromosomal fragment to be analyzed to identify the responsible genes and potential mutations that might influence the trait. Second, QTL chromosomal regions are mapped in experimental populations, developed in specific linkage disequilibrium (LD). Consequently, the QTLs mapped using experimental populations are not straightforwardly transferred to commercial lines, and require validation (Andersson, 2001; Harlizius et al., 2004). Nevertheless, segregation of QTLs associated with production traits, mapped in extreme crosses scheme, have been verified in commercial lines of chicken (De Koning et $a l ., 2003$; 2004). Despite all difficulties, examples of identification and use of QTLs have been shown to be possible in animal breeding. Two QTLs controlling milk composition and production were associated with mutations on dyacilglycerol O-acetyltransferase gene (DGAT1) (Grisart et al., 2002), and on the growth factor hormone receptor gene (Blott et al., 2003). In swine, QTLs influencing muscle mass and body fat deposition were identified near the IGF2 gene locus (Jeon et al., 1999; Nezer et al., 1999), and a single mutation was identified by sequencing a fragment of $30 \mathrm{~Kb}$ of this gene (van Laere et al., 2003). Considering the incomplete knowledge of biological mechanisms controlling complex economic traits, the potential use of markers associated with QTLs in assisted selection is even more troublesome. For example, growth largely involves additive genetic effects, with a few reports of epistasis for early growth (Hocking, 2005; Carlborg et al., 2003). Further, different QTLs control early and late growth, with very few affecting the entire process, indicating distinct regulatory control (Carlborg et al., 2003).

An ideal situation for quantitative genetic selection is a trait with high heritability and a phenotype that can be observed in all individuals before reproductive age. This ideal is hardly ever achieved, which limits the effectiveness of quantitative genetics selection (Dekkers; Hospital, 2002). These limitations can be alleviated by the "-omics" technologies, which attempt to give a comprehensive description of all the components from a species genome (genomics); expressed transcripts (mRNA) of the genome (transcriptomics); translated products of the transcripts (proteomics); and the complete set of metabolic components of the cell (metabolomics). These technologies can fundamentally change the practice of animal breeding from a basically "black-box" approach towards to one that considers the regulatory networks and pathways underlying 
the expression of important phenotypes (Kadarmideen et al., 2006). The "-omics" technologies provide an initial framework for breeders, who want to understand how genetic variation influences traits important for production of domestic animals, including chickens, by allowing the traits to be mapped back at a precise genomic location (Schmutz; Grimwood, 2004). Saturated genetic maps, containing many microsatellite and SNP markers, and possible haplotype maps containing QTLs, will theoretically have direct correspondence with the genome sequence in commercial or experimental populations. Identification of candidate genes and casual mutations will also be enabled by the direct access to genome sequences and to the transcriptome, by expressed sequence tags (ESTs, partial sequences obtained from one of the ends of a complementary DNA); and the re-sequencing of QTL intervals will be an attractive approach for positional cloning.

Chickens were the first livestock species to have their genome sequence published in 2004 (Hillier et al., 2004), based on DNA of a female of Gallus gallus gallus ('Red jungle fowl'), the ancestor of the domestic chicken. A comprehensive collection of ESTs has also been established for the most important tissues and embryonic developmental stages of chicken. More than 599,000 ESTs are available for Gallus gallus, deposited into the ESTs database (NCBI, dbEST, accessed in April, 2007). Abdrakhmanov et al., (2000) were the first to obtain chicken ESTs, selecting bursa as the target tissue, because of its importance to generate B and DT40 cell lines. The Biotechnology and Biological Sciences Research Council (BBSRC) has sequenced more than 340,000 ESTs (Boardman et al., 2002). The EST database provided evidence to identify 18,989 genes of the chicken genome, and for 19,626 full-sequence cDNA, which were essential for the genome annotation and a direct source to functional studies (Hubbard et al., 2005).

More than 2.8 million SNPs were identified comparing the genome sequence of the ancestor (Gallus gallus gallus) with those from domesticated lines: a broiler male ('White Cornish'), a layer female ('White Leghorn') and an ornamental female ('Silkie Chinese'), with an average substitution rate of five SNPs $\mathrm{Kb}^{-1}$ (Wong et al., 2004). The SNP map developed will be mainly used to increase marker density of linkage maps for QTL analysis and to identify genes and gene combinations that produce desirable traits in chicken breeding populations.

The collection of chicken sequences has also allowed the construction of array platforms for expression pattern analysis of thousands of transcripts simultaneously. A number of tissue-specific arrays has already been developed based on databases previously mentioned, including an intestine-specific array with 3,072 transcripts (Van Hemert et al., 2003); a macrophage-specific array containing 4,906 transcripts (Bliss et al., 2005); a lymphocyte-specific array with 3,011 clones (Neiman et al., 2001); an immune response-specific array with 5,000 genes (Smith et al., 2006); a heart precursor cell-specific array with 11,000 genes (Afrakhte; Schultheiss, 2004); among others. There are also microarrays representing 24 chicken embryonic and adult tissues (Burnside et al., 2005); and one containing 32,773 transcripts corresponding to over 28,000 chicken genes (http://www.affymetrix.com/products/arrays/specific/chicken.affx). These arrays represent fundamental tools to search for biological functions of genes using the tissuespecific expression pattern and, consequently, useful for a number of unsolved molecular puzzles that were not previously revealed using QTL mapping and high-throughput sequencing of the chicken genome. Further, expression analysis might turn out to be useful complement to QTL mapping for identifying genes that underlie complex traits (Andersson; Georges, 2004). 
Chicken genomics in Brazil: E.C. Jorge et al.

\section{Brazilian poultry genomics initiative}

The surge of poultry as a worldwide attractive business began during the Second World War. Food scarcity forced USA growers to start breeding programmes using 'New Hampshire' and 'Barred Plymouth Rock' breeds as progenitors, followed by 'Red Cornish' and 'White Cornish' with 'White Rock' (Souza; Michelan-Filho, 2004). In Brazil, before 1920-1930s, producers were stimulated to breed ornamental chicken lines for meat production. Later, American breeds were imported as genitors of the National Breeding Programme (Souza; Michelan-Filho, 2004), so all commercial broiler lines on the market nowadays have these breeds in their genetic background.

In the private sector the Aviagen group (Scotland, UK) has a breeding programme to develop broiler lines, with two commercial hybrids, called AgRoss 308 and AgRoss 508, already available for producers in Brazil. In the public sector, the breeding programme developed by 'Embrapa Suínos e Aves' (Concórdia, SC, Brazil) was established in the late 1980s, and several commercial broiler and layer lines have been recently launched, such as 'Embrapa 011', 'Embrapa 021' and 'Embrapa 031'. 'Embrapa Suínos e Aves' and the 'Universidade de São Paulo' ('Escola Superior de Agricultura Luiz de Queiroz', ESALQUSP, Piracicaba, SP, Brazil) had the strategic view to develop an experimental population specific for genomic studies, named 'EMBRAPA F2 Chicken Resource Population', segregating for main industrial and production traits, derived from crosses between a broiler and a layer line. Parental lines used presented distinct genetic composition, with the broiler line derived from crosses between 'Cornish', 'Hampshire' and 'White Plymouth Rock', whereas the layer line had the 'White Leghorn' breed as its background.

The broiler line, called TT, is a male line, and has been selected since 1992 for body weight, feed conversion, carcass and parts yields, chick viability, fertility, hatchability of fertile eggs, and reduced abdominal fat and metabolic disorders. The layer line, called CC, has been selected since 1989 for traits such as egg production, egg weight; feed conversion, chick viability, sexual maturity, fertility, hatchability of fertile eggs, egg quality and decreased body weight. The resource population was created from reciprocal crosses between both lines, in the proportion of one male for each female. The $F_{1}$ generation was obtained from crosses between seven males and seven females from each line, resulting in seven families from crosses between broiler males and layer females (TC), and seven families from reciprocal crosses between layer males and broiler females (CT). The $\mathrm{F}_{2}$ generation was derived from crosses between one male and three females from different $F_{1}$ families, randomly selected. A total of seven males and $21 F_{1}$ females from each cross (CT and TC) generated around $100 \mathrm{~F}_{2}$ chickens per $F_{1}$ family, in 17 hatches, in a total of approximately $4,000 \mathrm{~F}_{2}$ chickens, being half of each sex and half of each cross - TC and CT. Phenotypic traits, mainly associated with performance (body weight at 1, 35, 41 and 42 days of age, feed consumption and feed efficiency), carcass yield (breast, drums and thighs, and wings weight), carcass composition (water, crude protein, fat content, ash) and physiology (organs weight, triglyceride and cholesterol levels) were evaluated and recorded for these animals.

Structural and functional genomic analyses of this experimental population were started, firstly developing genetic maps for QTL identification, followed by searching for genes associated with skeletal muscle development to be used as candidate genes for selection of highly muscular animals. Genetic maps were developed using microsatellite markers, which allowed the identification of QTLs. For example, QTLs for performance and carcass traits were mapped on chromosome 1 (Nones et al., 2006), co-localized with QTLs affecting body, carcass, legs and wings weight, abdominal fat, and feed intake, previously mapped in other populations (van Kaam et al., 1999; Sewalem et al., 2002; Ikeobi et al., 2004). The overlap of QTLs mapped by independent experiments in distinct 
populations is rare, but highly important because they validate genomic regions as truly associated with the analyzed traits. Novel QTLs were also mapped on chromosome 1 for liver, gizzard, lungs, heart and feet weight, intestine length, and feed conversion (Nones et al., 2006). QTLs for feed conversion, abdominal fat, and for lung and heart weights are of great interest to the poultry industry, since these are difficult traits to measure and to select independently from body weight. The QTL mapping approach is still a recurrent theme, with the genetic maps currently being saturated to allow QTL mapping in other chromosomes, including the poorly represented micro-chromosomes, as well as the detection and estimation of epistatic QTL effects. QTL-defined regions have to be subsequently selected for a fine mapping approach, searching for effective linked markers or genes that can be used in MAS.

Phenotypic differences in muscle mass between TT and CC chicken lines can be detected from embryonic stages until adulthood. For example, after 17 days of embryonic development, the TT pectoralis muscle weighed $0.280 \mathrm{~g}$, while the one from CC weighed $0,190 \mathrm{~g}$. At twenty one-days post-hatch, a fivefold difference can be observed between TT and CC pectoralis muscle weight, with TT weighing $42 \mathrm{~g}$ and $\mathrm{CC}, 7.7 \mathrm{~g}$ (unpublished results). At slaughter age (41 days), the same five-fold difference can be observed, with TT weighing 2,395 g and CC, when reared as broilers, $513 \mathrm{~g}$, (Ledur et al., 2000a,b; Nones et al., 2006). These evidently contrasting phenotypic differences can also be observed in different broiler and layer lines, among different anatomical muscles (Scheuermann et al., 2004; Remignon et al., 1995; Burke; Henry, 1997; Tesseraud et al., 2000), and suggest that they are determined during early development. Coutinho et al., (1993) described a delay in somite formation (embryonic muscle precursor structures), in expression of transcription factors that determine the fate of the myogenic cells (called myogenic factors), and of myosin heavy chains in quail lines selected for growth in relation to controls. The delay in myogenic factors expression could be responsible for a superior presumptive myoblast and proliferation rate of myoblasts in the growth selected line, which occurs immediately before muscular differentiation initiation. Embryonic proliferation stages of myogenic precursors practically determine the number of mature muscle fibres in the adult animal (Christ; Brand-Saberi, 2002). The majority of the muscular growth observed after birth is caused by hypertrophy (Moss, 1968). Consequently, knowledge of the intricate molecular events that occur during myogenesis would allow revealing candidate genes capable of affecting muscle mass deposition potential in domestic animals.

Biological functions of the myogenic transcription factors during embryogenesis have already been well-established. MyoD/Myf5 double-null mutants were not able to form skeletal muscle cells, due to an absence of myogenic precursor cells (Rudnick et al., 1993). Absence of these factors changes the location of the precursor cells to abnormal sites of myogenesis, causing other cell fates (Tajbakhsh et al., 1996). MRF4, myogenin, and MyoD act later during myogenesis as differentiation factors (Hasty et al., 1993; Braun; Arnold, 1995). Based on these findings, the expression levels of the genes encoding known myogenic factors (MyoD, Myf5, myogenin and MRF4) and growth factors (IGF I and II, and TGF- $\beta$ ).were investigated in samples of pectoralis muscle dissected from the Embrapa broiler and layer chicken lines. Transcription analysis by quantitative RT-PCR revealed significantly lower levels of MyoD, Myf5 and myostatin in the broiler line (unpublished results), in agreement with the myogenesis delay previously observed in quail lines selected for growth (Coutinho et al., 1993).

The demonstration that genes encoding myogenic factors were differentially expressed between the lines suggested that MyoD, Myf5, myogenin, MRF4 and myostatin could be used to select animals with higher skeletal muscle deposition potential. Polymorphisms identified on the sequence of the myostatin gene have been exploited to be used in animal 
Chicken genomics in Brazil: E.C. Jorge et al.

selection for muscular potential. Myostatin is a known negative regulator of skeletal muscle growth. A loss-of-function mutation in the myostatin gene causes double muscling phenotype in 'Belgian Blue' and 'Piedmontese' cattle breeds (McPherron; Lee, 1997). Muscle weight of mice lacking the myostatin gene are about two or three times greater than those of wild type (McPherron et al., 1997). The generalized muscular hypertrophy caused by the loss of function of this gene has been positively selected in some cattle breeds. The effect of myostatin sequence polymorphisms were evaluated for important traits in three commercial broiler chicken lines (Ye et al., 2007), and significant associations $(\mathrm{P}<0.031)$ were found with growth, mortality, blood oxygen, and hen antibody titre to infectious bursal disease virus vaccine, suggesting a pleiotropic effect of the myostatin gene on broiler performance (Ye et al., 2007).

Simultaneously, ESTs have been generated from skeletal muscle precursors and adult tissues, and from hypophysis and hypothalamus, to identify new candidate genes associated with the myogenic programme and growth process, and also to generate a resource for gene expression studies. A total of eight cDNA libraries were constructed from somites (one library, stage HH15; Hamburger; Hamilton, 1951), limb buds in three development stages (one library, $\mathrm{HH} 21, \mathrm{HH} 24$ and HH26), whole embryo (one library, HH26) (Jorge et al., 2004), pectoralis muscle in different developmental stages for broiler and layer lines (pool of HH35 and HH43, for broiler and layer lines; and pool of one and 21 days post-hatch, just for the broiler line, in a total of three cDNA libraries), and the hypophysis and hypothalamus cDNA libraries from chickens with 21 days post-hatch, one for broiler and another for layer line (unpublished results). A total of 13,664 ESTs were generated from these cDNA libraries, which after clustering and assembly (CAP3, Huang; Madan, 1999), revealed 6,774 putative chicken genes or unique sequences. The ESTs were annotated based on the chicken and human genome, and ESTs obtained for chicken, human and mouse. All ESTs were deposited into the dbEST (NCBI, http://www.ncbi.nlm.nih.gov), identified as CD760792 to CD765430, C0502869 to C0507803 and CO419474 to CO423759. These ESTs represent an important source of novel genes in chicken, and they have been used to construct the first muscle-associated microarray platform for chicken, with 4,534 clones spotted in duplicate (unpublished results). This platform corresponds to an important tool for functional investigation of new genes, determining the expression pattern according to developmental stages, evaluating differences in muscular growth potential between lines, and for the identification of tissuespecific genes.

\section{Perspectives on the use of genomic approaches in breeding programmes and biological research}

QTLs underlying variation in economically important traits have been successfully identified in chicken (reviewed by Hocking, 2005; Abasht et al., 2006). The ultimate goals of these studies were to identify either genetic markers closely linked to QTLs (linkage disequilibrium markers) or the gene(s) responsible for the QTL (direct marker) to be used in MAS in breeding schemes (Abasht et al., 2006). These objectives have seldom been achieved because of the intrinsic limitations of the quantitative approach, but it still offers great potential by compiling results across independent studies with the identification of consistent QTLs (Hocking, 2005; Abasht et al., 2006).

The availability of the chicken genome sequence (Hillier et al., 2004) and the SNP genetic map (Wong et al., 2004) opened new possibilities for identifying QTLs (Abasht et al., 2006). Quantitative trait analysis has been facilitated by the adoption of SNPs as markers for genotyping (instead of microsatellites and RFLPs), as well as the 
implementation of association or admixture mapping based on LD between markers and important traits (Soller et al., 2006; Abasht et al., 2006). The main contribution will be the direct application of QTL-associated markers in commercial breeding programmes (Soller et al., 2006; Abasht et al., 2006). The large number of SNPs identified in the chicken genome will also eventually be available onto genomic oligonucleotide microarrays for applications in quantitative genetics, allowing genotyping with a dense SNP-set, in large sample sizes, quickly, accurately, with minimal optimization and with a feasible unit cost (Meaburn et al., 2005).

Further, expression microarrays and segregating populations available for chicken can also be used to identify expression QTLs (e-QTLs), in a novel approach named 'Genetical Genomics' (Jansen; Nap, 2001). A segregating pedigreed or resource population is mapped with genetic markers to identify QTLs, and simultaneously used for expression profiling for each individual. By treating the expression level of each gene on a microarray as a quantitative trait, these data allow the identification of genomic regions that affect or regulate gene expression phenotypes, known as e-QTL (Jansen; Nap, 2001; de Koning; Haley, 2005). The meaning of these e-QTL regions is that they might contain genes with significant effect on transcriptional regulation of some of the genomic regions associated with QTLs for the analyzed traits (Kadarmideen et al., 2006). Genetical genomics combining SNPs mapping data and QTL identification with microarray profiling on the same population would reveal cis and trans-e-QTL, and also SNP markers associated with phenotypic expression differences (Jansen; Nap, 2001; de Koning; Haley, 2005; Kadarmideen et al., 2006). This approach would enable functional identification of uncharacterized genes, and unravel gene and gene products involved in metabolic and regulatory networks, finally allowing the identification and elucidation of epistatic effects. e-QTL have been successfully associated with variation in disease phenotype in mice (Schadt et al., 2003) and rats (Hubner et al., 2005). Genetical genomics offers a unique potential to be used in chicken, because microarrays, SNP map and mapped resource populations are already available.

The availability of high-throughput measurements of gene products (e.g. proteome and metabolome) has enabled the collection of comprehensive data-sets on whole systems performance, which can be added to the complexity of metabolic and regulatory networks in association with phenotype evaluation under various ontogenetic and/or environmental conditions. Because a biological entity is not just a linear flow of information, a small scale analysis of gene products is not sufficient to predict the behaviour of the whole organism (Kitano, 2002). Thus, an integrative approach is emerging in this post-genomic era, called Systems Genetics or Systems Biology, depending on the development of statistical and analytical methods to link all the information obtained from genomics, transcriptomics, proteomics, metabolomics, computational biology, chemistry, protein biochemistry and mass spectrometry, to be incorporated into the already existing approaches of phenotypic selection, selection on DNA polymorphisms, and combination of both, for a more efficient application in animal breeding (Kitano, 2002; Cassman, 2005; Kadarmideen et al., 2006; Bogyo; Cravatt, 2007; Srivastava; Varner, 2007).

In a complementary approach, transient transgenesis has been used to study unknown, uncharacterized and/or 'bizarre' genes revealed by functional genomic analysis. Transient transgenesis is required to determine gene function in vivo, allowing the evaluation of phenotypic and genotypic effects of exogenous expression of the target gene. Chicken embryos are easily accessed and manipulated, and are consequently an excellent model system for functional studies. Methods of delivering expression constructs into chickenliving cells, such as retroviral vectors and electroporation, have resulted in sufficient amount of transfected cells after transformation (Krull, 2004; Bourikas, Stoeckli, 2003; Pekarik et al., 2003; Alvares et al., 2003). Further, chicken stable transgenesis has been 
Chicken genomics in Brazil: E.C. Jorge et al.

long envisioned with the description of the primary conceptual requirements for inserting designed genetic alterations into the chicken genome. Recently, studies using germline transmission of primordial germ cells to transfect chicken embryos have turned chicken transgenesis into a more efficient and unlimited process (van de Lavoir et al., 2006). The development of a facile cell-based system for introducing precise genetic modifications in the genome has opened new doors for chicken to resume a leading role in developmental biology and to gain a new role in the manufacture of biologics and therapeutics (Etches, 2006; Ivarie, 2003).

\section{Acknowledgment}

L.L. Coutinho, A. Figueira and E.C. Jorge are recipients of research productivity scholarship from Conselho Nacional de Desenvolvimento Científico e Technológico (CNPq).

\section{References}

ABASHT, B., DEKKERS, J.C. and LAMONT, S.J. (2006) Review of quantitative trait loci identified in the chicken. Poultry Science 85: 2079-96.

ABDRAKHMANOV, I., LODYGIN, D., GEROTH, P., ARAKAWA, H., LAW, A., PLACHY, J., KORN, B. and BUERSTEDDE, J.M. (2000) A large database of chicken bursal ESTs as a resource for the analysis of vertebrate gene function. Genome Research 10: 2062-2069.

AFRAKHTE, M. and SCHULTHEISS, T.M. (2004) Construction and analysis of a subtracted library and microarray of cDNAs expressed specifically in chicken heart progenitor cells. Developmental Dynamics 230 : 290-298.

AGARWAL, S.K., COGBURN, L.A. and BURNSIDE, J. (1994) Dysfunctional growth hormone receptor in a strain of sex-linked dwarf chicken: evidence for a mutation in the intracellular domain. The Journal of endocrinology 142: 427-34.

ALVARES, L.E., SCHUBERT, F.R., THORPE, C., MOOTOOSAMY, R.C., CHENG, L., PARKYN, G., LUMSDEN, A. and DIETRICH, S. (2003) Intrinsic, Hox-dependent cues determine the fate of skeletal muscle precursors. Developmental Cell 5(3): 379-90.

ANDERSSON, L. (2001) Genetic dissection of phenotypic diversity in farm animals. Nature Review Genetics 2: $130-138$.

ANDERSSON, L. and GEORGES, M. (2004) Domestic-animal genomics: deciphering the genetics of complex traits. Nature Reviews Genetics 5: 202-212.

BLISS, T.W., DOHMS, J.E., EMARA, M.G. and KEELER, C.L. Jr. (2005) Gene expression profiling of avian macrophage activation. Veterinary Immunology and Immunopathology 105: 289-299.

BLOTT, S., KIM, J.J., MOISIO, S., SCHMIDT-KUNTZEL, A., CORNET, A., BERZI, P., CAMBISANO, N., FORD, C., GRISART, B., JOHNSON, D., KARIM, L., SIMON, P., SNELL, R., SPELMAN, R., WONG, J., VILKKI, J., GEORGES, M., FARNIR, F. and COPPIETERS, W. (2003) Molecular dissection of a quantitative trait locus: a phenylalanine-to-tyrosine substitution in the transmembrane domain of the bovine growth hormone receptor is associated with a major effect on milk yield and composition. Genetics 163: 253-266.

BOARDMAN, P.E., SANZ-EZQUERRO, J., OVERTON, I.M., BURT, D.W., BOSCH, E., FONG, W.T., TICKLE, C., BROWN, W.R., WILSON, S.A. and HUBBARD, S.J. (2002) A comprehensive collection of chicken cDNAs. Current Biology 12: 1965-1969.

BOGYO, M. and CRAVATT, B.F. (2007) From genes to function: advances in applications of chemical and systems biology. Current Opinion in Chemical Biology 1:1-3.

BOTSTEIN, D., WHITE, R.L., SKOLNICK, M. and DAVIS, R.W. (1980) Construction of a genetic linkage map in man using restriction fragment length polymorphisms. American Journal of Human Genetics 32: $314-$ 331 .

BOURIKAS, D. and STOECKLI, E.T. (2003) New tools for gene manipulation in chicken embryos. Oligonucleotides 13: 411-9.

BRAUN, T. and ARNOLD, H.H. (1995) Inactivation of Myf-6 and Myf-5 genes in mice leads to alterations in skeletal muscle development. EMBO Journal 14: 1176-1186.

BROWN, W.R., HUBBARD, S.J., TICKLE, C. and WILSON, S.A. (2003) The chicken as a model for largescale analysis of vertebrate gene function. Nature Reviews Genetics 4: 87-98. 
BUERSTEDDE, J.M. and TAKEDA, S. (1991) Increased ratio of targeted to random integration after transfection of chicken B cell lines. Cell 67: 179-188.

BURKE, W.H. and HENRY, M.H. (1997) Characteristics of the pectoralis superficialis and semimembranosus of broiler strain chickens, bantam chickens, and the reciprocal crosses. Poultry Science 76: 767-773.

BURNSIDE, J., NEIMAN, P., TANG, J., BASOM, R., TALBOT, R., ARONSZAJN, M., BURT, D. and DELROW, J. (2005) Development of a cDNA array for chicken gene expression analysis. BMC Genomics 6 13-23.

BURT, D.W. (2002) Applications of biotechnology in the poultry industry. World's Poultry Science Journal 58 5-13.

BURT, D.W. (2005) Chicken genome: Current status and future opportunities. Genome Research 15: 1692-8.

CARLBORG, O., KERJE, S., SCHUTZ, K., JACOBSSON, L., JENSEN, P. and ANDERSSON, L. (2003) A global search reveals epistatic interaction between QTL for early growth in the chicken. Genome Research 13: $413-421$.

CARLBORG, O., JACOBSSON, L., AHGREN, P., SIEGEL, P. and ANDERSSON, L. (2006) Epistasis and the release of genetic variation during long-term selection. Nature Genetics 38: 418-420.

CASSMAN, M. (2005) Barriers to progress in systems biology. Nature 438: 1079.

CHAMBERS, J.R., SMITH, E.J., DUNNINGTON, E.A. and SIEGEL, P.B. (1993) Sex-linked feathering (K, k+) in chickens: a review. Poultry Science Review 5: 97-116.

CHRIST, B. and BRAND-SABERI, B. (2002) Limb muscle development. International Journal of Developmental Biology 46: 905-914.

COLLINGS, F.S., BROOKS, L.D. and CHAKRAVARTI, A. (1998) A DNA polymorphism discovery resource for research on human genetics variation. Genome Research 8: 1229-1231.

COUTINHO, L.L., MORRIS, J., MARKS, H.L., BUHR, R.J. and IVARIE, R. (1993) Delayed somite formation in a quail line exhibiting myofiber hyperplasia is accompanied by delayed expression of myogenic regulatory factors and myosin heavy chain. Development 117: 563-569.

DEKKERS, J.C.M. (2004) Commercial application of marker- and gene-assisted selection in livestock: strategies and lessons. Journal of Animal Science 82 E-suppl: E313-328.

DEKKERS, J.C.M. and HOSPITAL, F. (2002) The use of molecular genetics in the improvement of agricultural populations. Nature Reviews Genetics 3: 22-32

DE KONING, D.J., WINDSOR, D., HOCKING, P.M., BURT, D.W., LAW, A., HALEY, C.S., MORRIS, A. VINCENT, J. and GRIFFIN, H. (2003) Quantitative locus detection in commercial broiler lines using candidate regions. Journal of Animal Science 81:1158-1165.

DE KONING, D.J., HALEY, C.S., WINDSOR, D., HOCKING, P.M., GRIFFIN, H., MORRIS, A., VINCENT, J. and BURT, D.W. (2004) Segregation of QTL for production traits in commercial meat-type chickens. Genetical Research 83:211-220.

DE KONING, D.J. and HALEY, C.S. (2005) Genetical genomics in humans and model organisms. Trends in Genetics 21: 377-81.

ETCHES, R.J. (2006) The hard cell(s) of avian transgenesis. Transgenic Research 15: 521-526.

GRISART, B., COPPIETERS, W., FARNIR, F., KARIM, L., FORD, C., BERZI, P., CAMBISANO, N., MNI, M., REID, S., SIMON, P., SPELMAN, R., GEORGES, M. and SNELL, R. (2002) Positional candidate cloning of a QTL in dairy cattle: identification of a missense mutation in the bovine DGAT1 gene with major effect on milk yield and composition. Genome Research 12: 222-231.

HAMBURGER, V. and HAMILTON, H.L. (1951) A series of normal stages in the development of the chick embryo. Journal of Morphology 88: 49-92.

HARLIZIUS, B., VAN WIJK, R. and MERKS, J.W. (2004) Genomics for food safety and sustainable animal production. Journal of Biotechnology 113: 33-42.

HASTY, P., BRADLEY, A., MORRIS, J.H., EDMONDSON, D.G., VENUTI, J.M., OLSON, E.N. and KLEIN, W.H. (1993) Muscle deficiency and neonatal death in mice with a targeted mutation in the myogenin gene. Nature 364: 501-506.

HILL, W.G. (2005) A century of corn selection. Science 307: 683-684.

HILLIER, L.W., MILLER, W., BIRNEY, E., WARREN, W., HARDISON, R.C., PONTING, C.P., BORK, P., BURT, D.W., GROENEN, M.A., DELANY, M.E., DODGSON, J.B., CHINWALLA, A.T., CLIFTEN, P.F., CLIFTON, S.W., DELEHAUNTY, K.D., FRONICK, C., FULTON, R.S., GRAVES, T.A., KREMITZKI, C., LAYMAN, D., MAGRINI, V., MCPHERSON, J.D., MINER, T.L., MINX, P., NASH, W.E., NHAN, M.N., NELSON, J.O., ODDY, L.G., POHL, C.S., RANDALL-MAHER, J., SMITH, S.M., WALLIS, J.W., YANG, S.P., ROMANOV, M.N., RONDELLI, C.M., PATON, B., SMITH, J., MORRICE, D., DANIELS, L., TEMPEST, H.G., ROBERTSON, L., MASABANDA, J.S., GRIFFIN, D.K., VIGNAL, A., FILLON, V., JACOBBSON, L., KERJE, S., ANDERSSON, L., CROOIJMANS, R.P., AERTS, J., VAN DER POEL, J.J., ELLEGREN, H., CALDWELL, R.B., HUBBARD, S.J., GRAFHAM, D.V., KIERZEK, A.M., MCLAREN, S.R., OVERTON, I.M., ARAKAWA, H., BEATTIE, K.J., BEZZUBOV, Y., BOARDMAN, P.E., BONFIELD, J.K., CRONING, M.D., DAVIES, R.M., FRANCIS, M.D., HUMPHRAY, S.J., SCOTT, C.E., TAYLOR, R.G., TICKLE, C., BROWN, W.R., ROGERS, J., BUERSTEDDE, J.M., WILSON, S.A., STUBBS, L., OVCHARENKO, I., GORDON, L., 
Chicken genomics in Brazil: E.C. Jorge et al.

LUCAS, S., MILLER, M.M., INOKO, H., SHIINA, T., KAUFMAN, J., SALOMONSEN, J., SKJOEDT, K., WONG, G.K., WANG, J., LIU, B., WANG, J., YU, J., YANG, H., NEFEDOV, M., KORIABINE, M., DEJONG, P.J., GOODSTADT, L., WEBBER, C., DICKENS, N.J., LETUNIC, I., SUYAMA, M., TORRENTS, D., VON MERING, C., ZDOBNOV, E.M., MAKOVA, K., NEKRUTENKO, A., ELNITSKI, L., ESWARA, P., KING, D.C., YANG, S., TYEKUCHEVA, S., RADAKRISHNAN, A., HARRIS, R.S., CHIAROMONTE, F., TAYLOR, J., HE, J., RIJNKELS, M., GRIFFITHS-JONES, S., URETA-VIDAL, A., HOFFMAN, M.M., SEVERIN, J., SEARLE, S.M., LAW, A.S., SPEED, D., WADDINGTON, D., CHENG, Z., TUZUN, E., EICHLER, E., BAO, Z., FLICEK, P., SHTEYNBERG, D.D., BRENT, M.R., BYE, J.M., HUCKLE, E.J., CHATTERJI, S., DEWEY, C., PACHTER, L., KOURANOV, A., MOURELATOS, Z., HATZIGEORGIOU, A.G., PATERSON, A.H., IVARIE, R., BRANDSTROM, M., AXELSSON, E., BACKSTROM, N., BERLIN, S., WEBSTER, M.T., POURQUIE, O., REYMOND, A., UCLA, C., ANTONARAKIS, S.E., LONG, M., EMERSON, J.J., BETRAN, E., DUPANLOUP, I., KAESSMANN, H., HINRICHS, A.S., BEJERANO, G., FUREY, T.S., HARTE, R.A., RANEY, B., SIEPEL, A., KENT, W.J., HAUSSLER, D., EYRAS, E., CASTELO, R., ABRIL, J.F., CASTEllanO, S., CAMARA, F., PARRA, G., GUIGO, R., BOURQUE, G., TESLER, G., PEVZNER, P.A., SMIT, A., FULTON, L.A., MARDIS, E.R. and WILSON, R.K. (2004) Sequence and comparative analysis of the chicken genome provide unique perspectives on vertebrate evolution. Nature $\mathbf{4 3 2}$ : 695-716.

HOCKING, P.M. (2005) Review of QTL mapping results in chickens. World's Poultry Science Journal 61: 215 226.

HUANG, X. and MADAN, A. (1999) CAP3: A DNA sequence assembly program. Genome Research 9: 868877.

HUBBARD, S.J., GRAFHAM, D.V., BEATTIE, K.J., OVERTON, I.M., MCLAREN, S.R., CRONING, M.D., BOARDMAN, P.E., BONFIELD, J.K., BURNSIDE, J., DAVIES, R.M., FARRELL, E.R., FRANCIS, M.D., GRIFFITHS-JONES, S., HUMPHRAY, S.J., HYLAND, C., SCOTT, C.E., TANG, H., TAYLOR, R.G., TICKLE, C., BROWN, W.R., BIRNEY, E., ROGERS, J. and WILSON, S.A. (2005) Transcriptome analysis for the chicken based on 19,626 finished cDNA sequences and 485,337 expressed sequence tags. Genome Research 15: 174-183.

HUBNER, N., WALlACE, C.A., ZIMDAHL, H., PETRETTO, E., SCHULZ, H., MACIVER, F., MUELLER, M., HUMMEL, O., MONTI, J., ZIDEK, V., MUSILOVA, A., KREN, V., CAUSTON, H., GAME, L., BORN, G., SCHMIDT, S., MULLER, A., COOK, S.A., KURTZ, T.W., WHITTAKER, J., PRAVENEC, M. and AITMAN, T.J. (2005) Integrated transcriptional profiling and linkage analysis for identification of genes underlying disease. Nature Genetics 37: 243-53.

IKEOBI, C.O., WOOLLIAMS, J.A., MORRICE, D.R., LAW, A., WINDSOR, D., BURT, D.W. and HOCKING, P.M. (2002) Quantitative trait loci affecting fatness in the chicken. Animal Genetics 33: 428-35.

IKEOBI, C.O.N., WOOLLIAMS, J.A., MORRICE, D.R., LAW, A., WINDSOR, D., BURT, D.W. and HOCKING, P.M. (2004) Quantitative trait loci for meat yield and muscle distribution in a broiler layer cross. Livestock Production Science 87: 143-151.

IVARIE, R. (2003) Avian transgenesis: progress towards the promise. Trends in Biotechnology 21: 14-19.

JANSEN, R.C. and NAP, J.P. (2001) Genetical genomics: the added value from segregation. Trends in Genetics 17: 388-91.

JEON, J.T., CARlborG, O., TORnSTEN, A., GIUFFrA, E., AMARgER, V., CHARDON, P., ANDERSSON-EKLUND, L., ANDERSSON, K., HANSSON, I., LUNDSTROM, K. and ANDERSSON, L. (1999) A paternally expressed QTL affecting skeletal and cardiac muscle mass in pigs maps to the IGF2 locus. Nature Genetics 21: 157-158.

JORGE, E.C., MONTEIRO-VITORELO, C.B., ALVES, H.J., SILVA, C.S., BALAN, R.G., PATRÍCIO, M. and COUTINHO, L.L. (2004) EST analysis of mRNA expressed during embryogenesis in Gallus gallus. The International Journal of Developmental Biology 48: 333-337.

KADARMIDEEN, H.N., VON ROHR, P. and JANSS, L.L. (2006) From genetical genomics to systems genetics: potential applications in quantitative genomics and animal breeding. Mammalian Genome 17: 54864.

KAUFMANN, J. (1999) Co-evolving genes in MHC haplotypes: the "rule" for nonmammalian vertebrales? Immunogenetics 50: 228-236.

KITANO, H. (2002) Systems Biology: a brief overview. Science 295: 1662-1664.

KRULL, C.E. (2004) A primer on using in ovo electroporation to analyze gene function. Developmental Dynamics 229: 433-9.

LEDUR, M.C., ZANELLA, E.L., SCHMIDT, G.S., JAENISCH, F.R.F., SAATKAMP, M.G., BASSI, L.J. and COUTINHO, L.L. (2000a) Peso e caracterssticas de carcaça em linhagens utilizadas no desenvolvimento de populações referência para detecção de QTL em aves. Revista Brasileira de Ciência Avícola 2 (Suppl. 2): 73.

LEDUR, M.C., ZANELLA, E.L., SCHMIDT, G.S., JAENISCH, F.R.F., SILVA, V. S., VENTURA, L. and COUTINHO, L.L. (2000b) Divergence of Strains and Strain Crosses used to Develop New Reference Populations for QTL Studies in Poultry. Proceedings of the XXI World's Poultry Congress, Montreal, Canada. CD Rom: abstracts/aug22/LEDUR_1.doc. 
LIPKIN, E., FULTON, J., CHENG, H., YONASH, N. and SOLLER, M. (2002) Quantitative trait locus mapping in chickens by selective DNA pooling with dinucleotide microsatellite markers by using purified DNA and fresh or frozen red blood cells as applied to marker-assisted selection. Poultry Science 81: 283-92.

MCPHERRON, A.C., LAWLER, A.M. and LEE, S.J. (1997) Regulation of skeletal muscle mass in mice by a new TGF-beta superfamily member. Nature 387: 83-90.

MCPHERRON, A.C. and LEE, S.J. (1997) Double muscling in cattle due to mutations in the myostatin gene. Proceedings of the National Academy of Sciences of the United States of America 94: 12457-12461.

MEABURN, E., BUTCHER, L.M., LIU, L., FERNANDES, C., HANSEN, V., AL-CHALABI, A., PLOMIN, R., CRAIG, I., SCHALKWYK, L.C. (2005) Genotyping DNA pools on microarrays: tackling the QTL problem of large samples and large numbers of SNPs. BMC Genomics 6: 52.

MORISSON, M., LEMIERE, A., BOSC, S., GALAN, M., PLISSON-PETIT, F., PINTON, P., DELCROS, C., FEVE, K., PITEL, F., FILLON, V., YERLE, M. and VIGNAL, A. (2002) ChickRH6: a chicken wholegenome radiation hybrid panel. Genetics, selection, evolution 34: 521-533.

MOSS, E.P. (1968) The relationship between the dimensions of the fibres and the number of nuclei during normal growth of skeletal muscle in domestic fowl. American Journal of Anatomy 122: 555-564.

NEIMAN, P.E., RUDDELL, A., JASONI, C., LORING, G., THOMAS, S.J., BRANDVOLD, K.A., LEE, R.M., BURNSIDE, J. and DELROW, J. (2001) Analysis of gene expression during myc oncogene-induced lymphomagenesis in the bursa of Fabricius. Proceedings of the National Academy of Sciences of the United States of America 98: 6378-6383.

NEZER, C., MOREAU, L., BROUWERS, B., COPPIETERS, W., DETILLEUX, J., HANSET, R., KARIM, L., KVASZ, A., LEROY, P. and GEORGES, M. (1999) An imprinted QTL with major effect on muscle mass and fat deposition maps to the IGF2 locus in pigs. Nature Genetics 21: 155-156.

NONES, K., LEDUR, M.C., RUY, D.C., BARON, E.E., MELO, C.M., MOURA, A.S., ZANELLA, E.L., BURT, D.W. and COUTINHO, L.L. (2006) Mapping QTLs on chicken chromosome 1 for performance and carcass traits in a broiler x layer cross. Animal Genetics 37: 95-100.

PEKARIK, V., BOURIKAS, D., MIGLINO, N., JOSET, P., PREISWERK, S. and STOECKLI, E.T. (2003) Screening for gene function in chicken embryo using RNAi and electroporation. Nature Biotechnology 21: $93-$ 6.

REMIGNON, H., GARDAHAUT, M.F., MARCHE, G. and RICARD, F.H. (1995) Selection for rapid growth increases the number and the size of muscle fibres without changing their typing in chickens. Journal of Muscle Research and Cell Motility 16: 95-102.

REYNAUD, C.A., ANQUEZ, V., GRIMAL, H. and WEILL, J.C. (1987) A hyperconversion mechanism generates the chicken light chain preimmune repertoire. Cell 48: 379-388.

ROMANOV, M.N., SAZANOV, A.A. and SMIRNOV, A.F. (2004) First century of chicken gene study and mapping - a look back and forward. World's Poultry Science Journal 60: 19-41.

RUDNICKI, M.A., SCHNEGELSBERG, P.N., STEAD, R.H., BRAUN, T., ARNOLD, H.H. and JAENISCH, R. (1993) MyoD or Myf-5 is required for the formation of skeletal muscle. Cell 75: 1351-1359.

SCHADT, E.E., MONKS, S.A., DRAKE, T.A., LUSIS, A.J., CHE, N., COLINAYO, V., RUFF, T.G., MILligAN, S.B., LAMB, J.R., CAVET, G., LINSLEY, P.S., MAO, M., STOUGHTON, R.B. and FRIEND, S.H. (2003) Genetics of gene expression surveyed in maize, mouse and man. Nature 422: 297-302.

SCHEUERMANN, G.N., BILGILI, S.F., TUZUN, S. and MULVANEY, D.R. (2004) Comparison of chicken genotypes: myofiber number in pectoralis muscle and myostatin ontogeny. Poultry Science 83: 1404-1412.

SCHMID, M., NANDA, I. and BURT, D. (2005) Second report on chicken genes and chromosomes 2005 Cytogenetic and Genome Research 109: 415-479.

SCHMUTZ, J. and GRIMWOOD, J. (2004) Fowl Sequence. Nature 432: 679-680.

SEWALEM, A., MORRICE, D.M., LAW, A., WINDSOR, D., HALEY, C.S., IKEOBI, C.O.N., BURT, D.W. and HOCKING, P.M. (2002) Mapping quantitative trait loci for body weight at three, six and nine weeks of age in a broiler layer cross. Poultry Science 81: 1775-1781.

SIEGEL, P.B., DODGSON, J.B. and ANDERSSON, L. (2006) Progress from chicken genetics to the chicken genome. Poultry Science 85: 2050-2060.

SMITH, J., SPEED, D., HOCKING, P.M., TALBOT, R.T., DEGEN, W.G., SCHIJNS, V.E., GLASS, E.J. and BURT, D.W. (2006) Development of a chicken $5 \mathrm{~K}$ microarray targeted towards immune function. $B M C$ Genomics 7: 49-59.

SOLLER, M., WEIGEND, S., ROMANOV, M.N., DEKKERS, J.C. and LAMONT, S.J. (2006) Strategies to assess structural variation in the chicken genome and its associations with biodiversity and biological performance. Poultry Science 85: 2061-78.

SOUZA, E.M. and MICHELAN FILHO, T. (2004) Genética avícola. In: MENDES, A.A.; NÄÄS, I.A.; MACARI, M. (Ed). Produção de frangos de corte. FACTA, cap. 2: 23-35.

SRIVASTAVA, R. and VARNER, J. (2007) Emerging technologies: systems biology. Biotechnology Progress 23: 24-27.

TAJBAKHSH, S., BOBER, E., BABINET, C., POURNIN, S. ARNOLD, H.H. and BUCKINGHAM, M. (1996) Gene targeting the myf-5 locus with nlacZ reveals expression of this myogenic factor in mature skeletal muscle fibres as well as early embryonic muscle. Developmental Dynamics 206: 291-300. 
Chicken genomics in Brazil: E.C. Jorge et al.

TATSUDA, K. and FUJINAKA, K. (2001) Genetic mapping of the QTL affecting body weight in chickens using a F-2 family. British Poultry Science 42: 333-337.

TAUTZ, D. (1989) Hypervariability of simple sequences as a general source for polymorphic DNA markers. Nucleic Acids Research 17: 6463-6471.

TESSERAUD, S., CHAGNEAU, A.M. and GRIZARD, J. (2000) Muscle protein turnover during early development in chickens divergently selected for growth rate. Poultry Science 79: 1465-1471.

TRAAS, A.M., CASAL, M., HASKINS, M. and HENTHORN, P. (2006) Genetic counseling in the era of molecular diagnostics. Theriogenology 66: 599-605.

TUISKULA-HAAVISTO, M., HONKATUKIA, M., VILKKI, J., DE KONING, D.J., SCHULMAN, N.F. and MAKI-TANILA, A. (2002) Mapping of quantitative trait loci affecting quality and production traits in egg layers. Poultry Science 81: 919-27.

UBA (2005/2006) Annual Report. União Brasileira de Avicultura. Brazil (Internet site: http://www.uba.org.br/ubanews_files/rel_uba_2005_06.pdf).

VALLEJO, R.L., BACON, L.D., LIU, H.C., WITTER, R.L., GROENEN, M.A.M., HILLEL, J. and CHENG, H.H. (1998) Genetic mapping of quantitative trait loci affecting susceptibility to Marek's disease virus induced tumors in F-2 intercross chickens. Genetics 148: 349-360.

VAN DE LAVOIR, M.C., DIAMOND, J.H., LEIGHTON, P.A., MATHER-LOVE, C., HEYER, B.S., BRADSHAW, R., KERCHNER, A., HOOI, L.T., GESSARO, T.M., SWANBERG, S.E., DELANY, M.E. and ETCHES, R.J. (2006) Germline transmission of genetically modified primordial germ cells. Nature 441: 766-9.

VAN LAERE, A.S., NGUYEN, M., BRAUNSCHWEIG, M., NEZER, C., COLLETTE, C., MOREAU, L., ARCHIBALD, A.L., HALEY, C.S., BUYS, N., TALLY, M., ANDERSSON, G., GEORGES, M. and ANDERSSON, L. (2003) A regulatory mutation in IGF2 causes a major QTL effect on muscle growth in the pig. Nature 425: 832-836.

VAN HEMERT, S., EBBELAAR, B.H., SMITS, M.A. and REBEL, J.M. (2003) Generation of EST and microarray resources for functional genomic studies on chicken intestinal health. Animal Biotechnology 14: 133-143.

VAN KAAM, J.B.C.H.M., VAN ARENDONK, J.A.M., GROENEN, M.A.M., BOVENHUIS, H., VEREIJKEN, A.L.J., CROOIJMANS, R.P.M.A., VAN DER POEL, J.J. and VEENENDAAL, A. (1998) Whole genome scan for quantitative trait loci affecting body weight in chickens using a three generation design. Livestock Production Science 54: 133-150.

VAN KAAM, J.B.C.H.M., GROENEN, M.A.M., BOVENHUIS, H., VEENENDAAL, A., VEREIJKEN, A.L.J. and VAN ARENDONK, J.A.M. (1999) Whole genome scan in chickens for quantitative trait loci affecting growth and feed efficiency. Poultry Science 78: 15-23.

WARDECKA, B., OLSZEWSKI, R, JASZCZAK, K., ZIEBA, G., PIERZCHALA, M. and WICINSKA, K. (2002) Relationship between microsatellite marker alleles on chromosomes 1-5 originating from the Rhode Island Red and Green-legged Partrigenous breeds and egg production and quality traits in $\mathrm{F}(2)$ mapping population. Journal of Applied Genetics 43: 319-329.

WONG, G.K., LIU, B., WANG, J., ZHANG, Y., YANG, X., ZHANG, Z., MENG, Q., ZHOU, J., LI, D., ZHANG, J., NI, P., LI, S., RAN, L., LI, H., ZHANG, J., LI, R., LI, S., ZHENG, H., LIN, W., LI, G., WANG, X., ZHAO, W., LI, J., YE, C., DAI, M., RUAN, J., ZHOU, Y., LI, Y., HE, X., ZHANG, Y., WANG, J., HUANG, X., TONG, W., CHEN, J., YE, J., CHEN, C., WEI, N., LI, G., DONG, L., LAN, F., SUN, Y., ZHANG, Z., YANG, Z., YU, Y., HUANG, Y., HE, D., XI, Y., WEI, D., QI, Q., LI, W., SHI, J., WANG, M., XIE, F., WANG, J., ZHANG, X., WANG, P., ZHAO, Y., LI, N., YANG, N., DONG, W., HU, S., ZENG, C., ZHENG, W., HAO, B., HILLIER, L.W., YANG, S.P., WARREN, W.C., WILSON, R.K., BRANDSTROM, M., ELLEGREN, H., CROOIJMANS, R.P., VAN DER POEL, J.J., BOVENHUIS, H., GROENEN, M.A., OVCHARENKO, I., GORDON, L., STUBBS, L., LUCAS, S., GLAVINA, T., AERTS, A., KAISER, P., ROTHWELL, L., YOUNG, J.R., ROGERS, S., WALKER, B.A., VAN HATEREN, A., KAUFMAN, J., BUMSTEAD, N., LAMONT, S.J., ZHOU, H., HOCKING, P.M., MORRICE, D., DE KONING, D.J., LAW, A., BARTLEY, N., BURT, D.W., HUNT, H., CHENG, H.H., GUNNARSSON. U., WAHLBERG, P., ANDERSSON, L., KINDLUND, E., TAMMI, M.T., ANDERSSON, B., WEBBER, C., PONTING, C.P., OVERTON, I.M., BOARDMAN, P.E., TANG, H., HUBBARD, S.J., WILSON, S.A., YU, J., WANG, J. and YANG, H. (2004) A genetic variation map for chicken with 2.8 million single-nucleotide polymorphisms. Nature 432: 717-722.

YE, X., BROWN, S.R., NONES, K., COUTINHO, L.L., DEKKERS, J.C. and LAMONT, S.J. (2007) Associations of myostatin gene polymorphisms with performance and mortality traits in broiler chickens. Genetics, selection, evolution 39: 73-89.

YONASH, N., BACON, L.D., WITTER, R.L. and CHENG, H.H. (1999) High resolution mapping and identification of new quantitative trait loci (QTL) affecting susceptibility to Marek's disease. Animal Genetics 30: $126-135$. 